\title{
Observations on Nicotinic Acid Therapy in Hartnup Disease
}

\author{
PAUL W. K. WONG ${ }^{\star}$, A. M. LAMBERT, P. M. PILLAI, and P. M. JONES \\ From the Mental Retardation Research Unit and the University Unit, \\ Royal Manchester Children's Hospital
}

Nicotinamide deficiency is a well-recognized biochemical abnormality in untreated cases of Hartnup disease (Baron, Dent, Harris, Hart, and Jepson, 1956; de Laey, Hooft, Timmermans, and Snoeck, 1964). There is general agreement that nicotinamide or nicotinic acid therapy is effective in the prevention and cure of the pellagrinoid rash in these patients. There is also some evidence that nicotinic acid may be beneficial in the treatment of the neurological symptoms (Baron et al., 1956; Halvorsen and Halvorsen, 1963). In 1964 de Laey et al. reported that nicotinic acid therapy completely corrected the metabolic abnormalities in one patient under their study. This has never been observed in any other case reported in the literature. A confirmation of their observation is of primary importance, not only because nicotinic acid may be a curative treatment in Hartnup disease, but also because it may be a causal factor in the primary defect that has been demonstrated in the transport of tryptophan in these patients (Milne, Crawford, Girão, and Loughridge, 1960; Wong and Pillai, 1966). The present paper describes some biochemical observations before and during intensive nicotinic acid therapy in two cases of Hartnup disease. The clinical and biochemical abnormalities in these two patients have been previously reported (Wong and Pillai, 1966).

\section{Materials and Methods}

Oral L-tryptophan loading tests were performed before and during oral nicotinic acid therapy. $100 \mathrm{mg}$. L-tryptophan per kg. body weight was dissolved in orange squash and was given to the fasting patients in the morning. The patients were given a constant protein diet at regular meal times three days before and during the experiments. Similarly, oral L-tryptophan loading tests were performed in untreated normal children as controls. Heparinized venous blood was used for the estimation of tryptophan and amino acids. Plasma tryptophan was estimated by the method of Duggan

Received March 20, 1967.

* Present address: Mount Sinai Hospital, Chicago, Ill., U.S.A. and Udenfriend (1956). Urine was collected under ice without preservative in consecutive periods of 4 hours, for $\mathbf{4}$ hours before and $\mathbf{2 4}$ hours after the loading. Small aliquots from all the urine samples were immediately frozen after collection. Urinary indican (indoxyl sulphate) was estimated by a modification of the method of Sharlit (1933); kynurenine was estimated by a modification of the method of Coppini, Benassi, and Montorsi (1959); indole-3-acetic acid was estimated by the method of Weissbach, King, Sjoerdsma, and Udenfriend (1959); and urine tryptophan was estimated by paper chromatography, using a solvent of butanol-acetic acid-water (12:3:5) and staining with Ehrlich solution. 24-hour urine was estimated for total nitrogen by the microKjeldahl method, for amino nitrogen by the method of Albanese and Irby (1944), and for $\mathrm{N}^{\prime}$-methylnicotinamide by the method of Carpenter and Kodicek (1950). Both plasma and urinary amino acids were estimated by a modification of the method of Moore, Spackman, and Stein (1958), with a Technicon amino acid autoanalyser. An 8-hour urine collection (midnight to $8.0 \mathrm{a}$.m.), with blood taken at the end of this period, was used for the estimation of the renal clearance of amino acids. Renal clearance of amino acids was calculated as $\mathrm{ml}$. of blood cleared of the particular amino acid per minute per 1.73 square metres of body surface, according to the following formula:

$$
\mathrm{Cm}=\frac{\mathrm{U}}{\mathrm{P}} \times \mathrm{V} \times \frac{1 \cdot 73,}{\mathrm{SA}}
$$

where $\mathrm{Cm}=\mathrm{ml}$. blood cleared per minute; $\mathrm{U}=\mathrm{mg}$. amino acid $/ 100 \mathrm{ml}$. urine; $\mathrm{P}=\mathrm{mg}$. amino acid $/ 100 \mathrm{ml}$. plasma; $\mathrm{V}=\mathrm{ml}$. urine excreted/minute; and $\mathrm{SA}=$ square metre of body surface area.

\section{Results}

Both patients (previously reported as Case 1 and Case 2) were treated initially with $50 \mathrm{mg}$. nicotinic acid orally per day. After 2 months of therapy, an oral tryptophan loading test was performed in Case 2 , without any improvement in his biochemical findings. Similarly in Case 1, after 5 months of therapy, repeated tests did not show an improvement in the excessive excretion of amino nitrogen in the urine or the abnormal amino acid pattern in the paper chromatograms of urine. 
In order to ensure that the patients received adequate doses of nicotinic acid, they were admitted to the Royal Manchester Children's Hospital. Case 1 was given $150 \mathrm{mg}$. nicotinic acid daily in three divided oral doses at meal times. After 4 days of therapy, a tryptophan load was given. Case 2 was given $300 \mathrm{mg}$. nicotinic acid daily in three divided oral doses at meal times, for 4 days before the tryptophan load. During these periods of high nicotinic acid intake both cases excreted higher than average amounts of $\mathrm{N}^{\prime}$-methylnicotinamide, Case 2 more markedly than Case 1 ; indicating that both patients were no longer deficient in nicotinic acid or nicotinamide at the time of the tryptophan loading tests (see Table VI).

Table I shows the plasma levels of tryptophan in both cases and in 5 controls after oral loading; while there was a doubtful improvement in the intestinal absorption of tryptophan in Case 1, there was no similar improvement in Case 2.

Table II shows the urinary excretion of kynurenine after tryptophan loading. In both patients there was a consistently higher output of kynurenine in the urine during the period of high nicotinic acid
TABLE I

Plasma Tryptophan (mg./10o ml.) After Tryptophan Loading

\begin{tabular}{|c|c|c|c|c|c|c|}
\hline & & \multicolumn{2}{|c|}{ Case 1} & \multicolumn{2}{|c|}{ Case 2} & Mean of \\
\hline \multicolumn{2}{|c|}{$\begin{array}{c}\text { Dosage of } \\
\text { nicotinic } \\
\text { acid per day (mg.) }\end{array}$} & 0 & 150 & 0 & 300 & 0 \\
\hline $\begin{array}{l}0 \text { hour } \\
2 \text { hours } \\
4 \text { hours } \\
6 \text { hours } \\
8 \text { hours }\end{array}$ & $\begin{array}{l}\cdots \\
\cdots \\
\cdots \\
\cdots\end{array}$ & $\begin{array}{l}1 \cdot 0 \\
2 \cdot 3 \\
2 \cdot 0 \\
2 \cdot 0 \\
1 \cdot 9\end{array}$ & $\begin{array}{l}1 \cdot 2 \\
5 \cdot 0 \\
3 \cdot 2 \\
2 \cdot 7 \\
2 \cdot 2\end{array}$ & $\begin{array}{l}1 \cdot 7 \\
3 \cdot 2 \\
4 \cdot 1 \\
2 \cdot 5 \\
2 \cdot 8\end{array}$ & $\begin{array}{l}1 \cdot 0 \\
2 \cdot 7 \\
1 \cdot 8 \\
1 \cdot 5 \\
1 \cdot 5\end{array}$ & $\begin{array}{l}1 \cdot 58 \\
8 \cdot 56 \\
6 \cdot 64 \\
2 \cdot 42 \\
1 \cdot 70\end{array}$ \\
\hline
\end{tabular}

intake. However, it is seen that the increase was delayed and was less when compared with that observed in the controls.

Table III shows the urinary excretion of indican. No reduction of the abnormally high output of indican was observed in either patient during the treatment periods.

Table IV shows the urinary excretion of indole-3acetic acid. Both patients appeared to have a reduction of indole-3-acetic acid excretion when

TABLE II

Urinary Kynurenine ( $\mu g . / k g$. per 4 hours) After Loading

\begin{tabular}{|c|c|c|c|c|c|c|c|c|c|c|}
\hline & & & & \multicolumn{2}{|c|}{ Case 1} & \multicolumn{4}{|c|}{ Case 2} & \multirow{2}{*}{$\frac{\begin{array}{c}\text { Mean of } \\
3 \text { Controls }\end{array}}{0}$} \\
\hline \multicolumn{4}{|c|}{ Dosage of nicotinic acid (mg.) } & 0 & 150 & 0 & 0 & 50 & 300 & \\
\hline-4 to 0 hours... & . & . & $\ldots$ & 130 & 194 & 170 & 92 & 123 & 176 & 33 \\
\hline $\begin{array}{l}0 \text { to } 4 \text { hours } \\
4 \text { to } 8 \text { hours } . \\
8 \text { to } 12 \text { hours } . \\
12 \text { to } 16 \text { hours . } \\
16 \text { to } 20 \text { hours . } \\
20 \text { to } 24 \text { hours... }\end{array}$ & $\begin{array}{l}\cdots \\
\cdots \\
\cdots \\
\cdots\end{array}$ & $\begin{array}{l}\ldots \\
\ldots \\
\cdots \\
\cdots\end{array}$ & \begin{tabular}{l|}
$\cdots$ \\
$\cdots$ \\
$\cdots$ \\
$\cdots$ \\
$\cdots$
\end{tabular} & $\begin{array}{r}50 \\
170 \\
180 \\
60 \\
64 \\
231\end{array}$ & $\begin{array}{l}150 \\
445 \\
230 \\
153 \\
180 \\
160\end{array}$ & $\begin{array}{l}218 \\
206 \\
157 \\
121 \\
194 \\
352\end{array}$ & $\begin{array}{r}171 \\
177 \\
218 \\
94 \\
171\end{array}$ & $\begin{array}{r}303 \\
339 \\
266 \\
76 \\
262 \\
273\end{array}$ & $\begin{array}{l}133 \\
629 \\
114 \\
193 \\
307\end{array}$ & $\begin{array}{r}737 \\
483 \\
305 \\
61 \\
80 \\
70\end{array}$ \\
\hline$\mu g . /$ kg. 24 hours & $\ldots$ & $\ldots$ & $\ldots$ & 755 & 1318 & 1248 & 831 & 1519 & 1376 & 1736 \\
\hline
\end{tabular}

$\star$ No urine voided.

TABLE III

Urinary Indican (mg./kg. per 4 hours) After Loading

\begin{tabular}{|c|c|c|c|c|c|c|c|c|c|c|}
\hline & & & & \multicolumn{2}{|c|}{ Case 1} & \multicolumn{4}{|c|}{ Case 2} & \multirow{2}{*}{$\frac{\begin{array}{c}\text { Mean of } \\
3 \text { Controls }\end{array}}{0}$} \\
\hline \multicolumn{4}{|c|}{ Dosage of nicotinic acid (mg.) } & 0 & 150 & 0 & 0 & 50 & 300 & \\
\hline-4 to 0 hours.. & . & . & . & $2 \cdot 83$ & $3 \cdot 90$ & $3 \cdot 60$ & $2 \cdot 55$ & $3 \cdot 58$ & $3 \cdot 53$ & $0 \cdot 760$ \\
\hline $\begin{array}{l}0 \text { to } 4 \text { hours } \\
4 \text { to } 8 \text { hours } . . \\
8 \text { to } 12 \text { hours .. } \\
12 \text { to } 16 \text { hours. } \\
16 \text { to } 20 \text { hours.. } \\
20 \text { to } 24 \text { hours .. }\end{array}$ & $\begin{array}{l}\cdots \\
\cdots \\
\cdots \\
\cdots\end{array}$ & $\begin{array}{l}\cdots \\
\cdots \\
\cdots \\
\cdots\end{array}$ & $\begin{array}{l}\ldots \\
\cdots \\
\cdots \\
\cdots \\
\cdots\end{array}$ & $\begin{array}{l}1 \cdot 77 \\
1 \cdot 84 \\
2 \cdot 13 \\
2 \cdot 25 \\
1 \cdot 93 \\
8 \cdot 51\end{array}$ & $\begin{array}{r}1 \cdot 44 \\
11 \cdot 50 \\
15 \cdot 20 \\
3 \cdot 84 \\
3 \cdot 71 \\
15 \cdot 75\end{array}$ & $\begin{array}{l}1 \cdot 52 \\
1 \cdot 15 \\
0 \cdot 54 \\
1 \cdot 00 \\
2 \cdot 90 \\
6 \cdot 42\end{array}$ & $\begin{array}{r}1 \cdot 00 \\
1 \cdot 76 \\
3 \cdot 12 \\
4 \cdot 82 \\
11 \cdot 9\end{array}$ & $\begin{array}{r}5 \cdot 09 \\
4 \cdot 61 \\
7 \cdot 76 \\
4 \cdot 48 \\
13 \cdot 09 \\
9 \cdot 70\end{array}$ & $\begin{array}{l}2 \cdot 40 \\
3 \cdot 50 \\
0 \cdot 67 \\
3 \cdot 25 \\
3 \cdot 14\end{array}$ & $\begin{array}{l}0.810 \\
0.686 \\
0.334 \\
0.455 \\
1.680 \\
0.908\end{array}$ \\
\hline mg./kg. 24 hours & . & . & . & $18 \cdot 43$ & $51 \cdot 44$ & $13 \cdot 53$ & $22 \cdot 53$ & $44 \cdot 73$ & $12 \cdot 96$ & $4 \cdot 873$ \\
\hline
\end{tabular}

$\star$ No urine voided. 
TABLE IV

Urinary Indole-3-acetic Acid (mg./kg. per 4 hours) After Loading

\begin{tabular}{|c|c|c|c|c|c|c|c|c|c|c|}
\hline & & & & \multicolumn{2}{|c|}{ Case 1} & \multicolumn{4}{|c|}{ Case 2} & \multirow{2}{*}{$\frac{\begin{array}{c}\text { Mean of } \\
3 \text { Controls }\end{array}}{0}$} \\
\hline \multicolumn{4}{|c|}{ Dosage of nicotinic acid (mg.) } & 0 & 150 & 0 & 0 & 50 & 300 & \\
\hline-4 to 0 hours.. & . & . & $\ldots$ & $0 \cdot 20$ & $0 \cdot 35$ & 0.95 & $0 \cdot 14$ & $0 \cdot 14$ & 0.09 & 0.054 \\
\hline $\begin{array}{l}0 \text { to } 4 \text { hours } \\
4 \text { to } 8 \text { hours } . \\
8 \text { to } 12 \text { hours } . \\
12 \text { to } 16 \text { hours.. } \\
16 \text { to } 20 \text { hours. } \\
20 \text { to } 24 \text { hours.. }\end{array}$ & $\begin{array}{l}\cdots \\
\cdots \\
\cdots \\
\cdots \\
\cdots\end{array}$ & $\begin{array}{l}\cdots \\
\cdots \\
\cdots \\
\cdots \\
\cdots\end{array}$ & $\begin{array}{l}\cdots \\
\cdots \\
\cdots \\
\cdots\end{array}$ & $\begin{array}{l}0 \cdot 08 \\
2 \cdot 12 \\
1 \cdot 29 \\
0 \cdot 37 \\
0 \cdot 30 \\
2 \cdot 54\end{array}$ & $\begin{array}{l}0 \cdot 05 \\
0 \cdot 62 \\
0 \cdot 94 \\
0 \cdot 20 \\
0 \cdot 17 \\
0 \cdot 80\end{array}$ & $\begin{array}{l}0.47 \\
0.57 \\
0.65 \\
0.83 \\
0.48 \\
2 \cdot 67\end{array}$ & $\begin{array}{l}0 \cdot 07 \\
0 \cdot 65 \\
1 \cdot 98 \\
1 \cdot 47 \\
2 \cdot{ }^{\star} \\
2 \cdot 39\end{array}$ & $\begin{array}{l}0 \cdot 22 \\
0 \cdot 52 \\
1 \cdot 18 \\
0 \cdot 87 \\
1 \cdot 50 \\
1 \cdot 64\end{array}$ & $\begin{array}{l}0.12 \\
0.23 \\
0.15 \\
0 . \\
0.50 \\
0.93\end{array}$ & $\begin{array}{l}0.344 \\
0 \cdot 208 \\
0.056 \\
0.033 \\
0.054 \\
0.088\end{array}$ \\
\hline mg./kg. 24 hours & . & . & $\ldots 1$ & $6 \cdot 70$ & $2 \cdot 78$ & $5 \cdot 67$ & $6 \cdot 56$ & $5 \cdot 93$ & $1 \cdot 93$ & 0.783 \\
\hline
\end{tabular}

$\star$ No urine voided.

TABLE V

Urinary Tryptophan (mg./kg. per 4 hours) After Loading

\begin{tabular}{|c|c|c|c|c|c|c|c|c|c|c|}
\hline & & & & \multicolumn{2}{|c|}{ Case 1} & & \multicolumn{2}{|c|}{ Case 2} & & $\begin{array}{c}\text { Mean of } \\
2 \text { Controls }\end{array}$ \\
\hline \multicolumn{4}{|c|}{ Dosage of nicotinic acid (mg.) } & 0 & 150 & 0 & 0 & 50 & 300 & 0 \\
\hline-4 to 0 hours .. & . & . & $\ldots$ & $6 \cdot 10$ & $0 \cdot 78$ & $1 \cdot 10$ & $0 \cdot 37$ & $1 \cdot 09$ & $0 \cdot 08$ & 0.02 \\
\hline $\begin{array}{l}0 \text { to } 4 \text { hours } \\
4 \text { to } 8 \text { hours } \\
8 \text { to } 12 \text { hours } . . \\
12 \text { to } 16 \text { hours. } \\
16 \text { to } 20 \text { hours.. } \\
20 \text { to } 24 \text { hours... }\end{array}$ & $\begin{array}{l}\ldots \\
\ldots \\
\ldots \\
\ldots\end{array}$ & $\begin{array}{l}\cdots \\
\cdots \\
\cdots \\
\cdots \\
\cdots\end{array}$ & \begin{tabular}{l|}
$\cdots$ \\
$\cdots$ \\
$\cdots$ \\
$\cdots$ \\
$\cdots$
\end{tabular} & $\begin{array}{r}10 \cdot 60 \\
9 \cdot 20 \\
5 \cdot 00 \\
2 \cdot 00 \\
1 \cdot 70 \\
8 \cdot 00\end{array}$ & $\begin{array}{l}0 \cdot 80 \\
0.95 \\
0 \cdot 17 \\
0 \cdot 13 \\
0 \cdot 23 \\
1 \cdot 18\end{array}$ & $\begin{array}{l}3 \cdot 15 \\
1 \cdot 45 \\
0 \cdot 73 \\
0 \cdot 79 \\
1 \cdot 39 \\
2 \cdot 97\end{array}$ & $\begin{array}{l}0 \cdot 80 \\
1 \cdot 04 \\
0 \cdot 80 \\
0.53 \\
1 \cdot 2 \\
1 \cdot 29\end{array}$ & $\begin{array}{l}2 \cdot 06 \\
1 \cdot 45 \\
1 \cdot 21 \\
1 \cdot 09 \\
2 \cdot 55 \\
2 \cdot 30\end{array}$ & $\begin{array}{l}0.08 \\
0 \cdot 50 \\
0 \cdot 15 \\
-{ }^{\star} \\
0.73 \\
0.64\end{array}$ & $\begin{array}{l}0 \cdot 15 \\
0 \cdot 37 \\
0 \cdot 07 \\
0 \cdot 08 \\
0 \cdot 08 \\
0 \cdot 13\end{array}$ \\
\hline mg. $/ \mathrm{kg} .24$ hours & • & . & $\ldots$ & $36 \cdot 50$ & $3 \cdot 46$ & $10 \cdot 48$ & $4 \cdot 46$ & $10 \cdot 66$ & $2 \cdot 10$ & $0 \cdot 88$ \\
\hline
\end{tabular}

* No urine voided.

TABLE VI

24-hour Excretion (without tryptophan loading)

\begin{tabular}{|c|c|c|c|c|c|c|c|c|c|c|}
\hline & & \multicolumn{4}{|c|}{ Case 1} & \multicolumn{4}{|c|}{ Case 2} & \multirow{2}{*}{$\begin{array}{c}\begin{array}{c}\text { Normal } \\
\text { Controls }\end{array} \\
0\end{array}$} \\
\hline Dosage of nicotinic acid per day (mg.) & & 0 & 0 & 150 & 150 & 0 & 0 & 300 & 300 & \\
\hline $\begin{array}{l}\text { 24-hour urine excretion of } \\
\text { N'-methylnicotinamide (mg.) } \\
\text { 24-hour urine total nitrogen (mg.) } \\
\text { 24-hour urine amino nitrogen (mg.) } \\
\text { Amino nitrogen as \% of total nitrogen }\end{array}$ & $\begin{array}{l}\cdots \\
\cdots \\
\cdots\end{array}$ & $\begin{array}{r}1 \cdot 2 \\
5169 \\
543 \\
10 \cdot 5\end{array}$ & $\begin{array}{r}3 \cdot 7 \\
5332 \\
453 \\
8 \cdot 5\end{array}$ & $\begin{array}{r}3 \overline{192} \\
479 \\
15 \cdot 0\end{array}$ & $\begin{array}{r}5 \cdot 2 \\
5548 \\
787 \\
14 \cdot 2\end{array}$ & $\begin{array}{r}1 \cdot 54 \\
2941 \\
430 \\
14 \cdot 6\end{array}$ & $\begin{array}{r}0.94 \\
4244 \\
499 \\
11 \cdot 8\end{array}$ & $\begin{array}{r}18 \cdot 8 \\
3656 \\
469 \\
12 \cdot 8\end{array}$ & $\begin{array}{r}20 \cdot 5 \\
3235 \\
344 \\
10 \cdot 6\end{array}$ & $\begin{array}{c}3-4 \cdot 5 \\
3750-5880 \\
12-42 \\
0 \cdot 5-2\end{array}$ \\
\hline
\end{tabular}

they were given large doses of nicotinic acid. However, in both cases the output was in excess of that in the controls.

Table $\mathrm{V}$ shows the urinary excretion of tryptophan. High doses of nicotinic acid appeared to have improved the reabsorption of tryptophan in the renal tubules in both cases. However, the total 24-hour excretion was still above that of the controls.

Table VI shows the total 24-hour excretion of $\mathrm{N}^{\prime}$-methylnicotinamide, total nitrogen, and amino nitrogen. It is seen that without treatment the patients excreted subnormal amounts of $\mathrm{N}^{\prime}$-methylnicotinamide, while on high doses of nicotinic acid they excreted higher than average amounts of this metabolite. Both patients excreted 10 times or more amino nitrogen in the urine than the controls. There was no significant reduction in its excretion during the treatment periods. Similarly, the ratios of amino nitrogen to total nitrogen in the urine remained about 10 times higher than the normal.

Table VII shows the clearances of amino acids 
TABLE VII

Renal Clearance of Amino Acids (without tryptophan loading) (ml. plasma cleared/min. per 1.73 sq. m.)

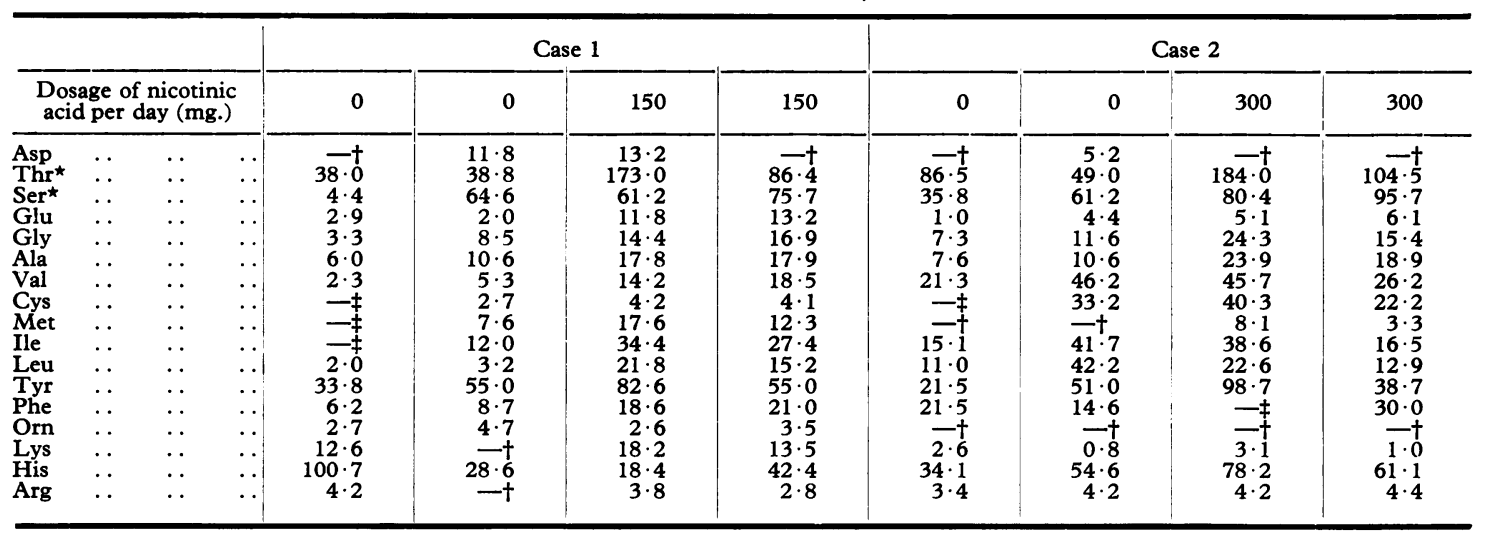

* Threonine and serine peaks contain glutamine and asparagine.

+ Not detected in the urine.

$\mp$ Not detected in the plasma.

in the patients before and during treatment. It should be noted that the method of column chromatography used in this study did not separate the threonine and serine peaks from glutamine and asparagine; they were, therefore, overestimated. It should also be noted that tryptophan was destroyed by this method It is seen that with the exception of lysine in Case 2, the clearance of the amino acids was abnormally raised. These values are similar to those reported by Evered (1956). Treatment, in the dosage and for the duration given in our 2 patients, did not correct the abnormal amino acid clearances. This confirms the persistent aminoaciduria, as indicated by the continuing high 24-hour excretion of amino nitrogen.

\section{Discussion}

In the untreated cases of Hartnup disease, there is a gross generalized aminoaciduria, hypertryptophanuria, hyperindoluria, and a reduced excretion of kynurenine and $\mathrm{N}^{\prime}$-methylnicotinamide. Due to the small number of cases and the variable and intermittent nature of the clinical signs and symptoms in this disease, assessment of the effectiveness of therapy has been difficult and insufficiently documented. With the exception of one case (de Laey et al., 1964) no one has reported a reversal to normal of the biochemical abnormalities in this disease.

De Laey et al. state that in their patient, following 2 weeks' treatment with $30 \mathrm{mg}$. nicotinic acid daily, 'observations were in favour of a complete normalization of the elimination of tryptophan metabolites'. Oral tryptophan loading tests showed that on nicotinic acid therapy, the excessive urinary excretion of tryptophan was reduced to normal; there was an increase in the amount of indole-3-acetic acid excreted; a reduction of the hyperaminoaciduria; a disappearance of the indicanuria; and the urinary excretion of kynurenine was the same as that of the treated controls. However, it should be noted that the amount of kynurenine excreted during the period of treatment for both the patient and the treated controls was only one-quarter to one-third of the untreated controls. Under nicotinic acid therapy neither indole nor tryptophan was detected in the faeces. De Laey et al. explained their results as follows: (1) nicotinic acid improves the absorption of tryptophan and other amino acids in the intestine and renal tubules; (2) nicotinic acid inhibits the activity of tryptophanase of the intestinal bacteria, resulting in the cessation of the formation of indolic metabolites which are responsible for the inhibition of tryptophan pyrrolase and formylase; (3) nicotinic acid enhances the kynurenine pathway, leading to increased excretion of $\mathrm{N}^{\prime}$ methylnicotinamide.

Our observations in 2 patients differed from those of de Laey et al. in several respects. (1) Nicotinic acid therapy did not bring about normal tryptophan absorption in the intestine or in the renal tubules. This was indicated by the low levels of plasma tryptophan attained after oral loading, and by the higher than normal amount of tryptophan excreted in the urine during therapy. (2) Nicotinic acid did not abolish the formation and the excessive excretion of indican. (3) During nicotinic acid therapy, no improvement in the gross aminoaciduria was observed. On the other hand, there was a suggestion of improvement in the output 
of kynurenine, and a reduction in the urinary excretion of tryptophan and indole-3-acetic acid towards normal levels. The data obtained in the present study do not provide any explanation for these changes; nor is there any obvious cause for the difference in the effect of nicotinic acid therapy in our patients and that of de Laey et al.

It appears that if the hypotheses of de Laey et al. are correct, the high doses of nicotinic acid should not only cure the clinical signs and symptoms but also cause the biochemical picture to become normal. In addition, the high doses of nicotinic acid given to our patients should have been adequate to produce a 'pharmacological effect' and correct the abnormal biochemical findings. The present study failed to confirm the observations of de Laey et al.

This difference in the effect of nicotinic acid on the metabolic abnormalities in the patient of de Laey $e t$ al. and the two cases of our own raises the possibility that there may be different variants of Hartnup disease.

\section{Summary}

The effect of nicotinic acid on tryptophan metabolism was studied in two cases of Hartnup disease. No correction of the metabolic abnormalities was observed after an extended period of nicotinic acid therapy, though there was a suggestion of improvement in some of the abnormal findings. Further studies in this disorder are required before we can recommend treatment with higher than replacement doses of nicotinic acid for long periods of time.

The authors wish to thank the Research Committee of the Manchester Regional Hospital Board, the Rag Fund of the University of Manchester, the Wellcome
Trust, and the Swinton and Pendlebury Branch of the National Society for Mentally Handicapped Children for their financial assistance. They also wish to thank Professor Wilfrid Gaisford and Dr. Neil Gordon for their permission to study their cases, Dr. E. Kodicek for his help in the determination of $\mathrm{N}^{\prime}$-methylnicotinamide, and Dr. G. M. Komrower for his advice and for reviewing the manuscript. One of the authors (P.W. $\mathrm{K}$.W.) is supported by a grant from the Children's Research Fund.

\section{REFERENCES}

Albanese, A. A., and Irby, V. (1944). Determination of urinary amino nitrogen by the copper method. f. biol. Chem., 153, 583.

Baron, D. N., Dent, C. E., Harris, H., Hart, E. W., and Jepson, J. B. (1956). Hereditary pellagra-like skin rash with temporary cerebellar ataxia, constant renal amino-aciduria, and other bizarre biochemical features. Lancet, $2,421$.

Carpenter, K. J., and Kodicek, E. (1950). The fluorimetric estimation of $N^{\prime}$-methylnicotinamide and its differentiation from co-enzyme 1. Biochem. F., 46, 421.

Coppini, D., Benassi, C. A., and Montorsi, M. (1959). Quantitative determination of tryptophan metabolites (via kynurenine) in biologic fluids. Clin. Chem., 5, 391.

de Laey, P., Hooft, C., Timmermans, J., and Snoeck, J. (1964). Biochemical aspects of the Hartnup disease. Ann. paediat. (Basel), 202, 145, 253, and 321.

Duggan, D. E., and Udenfriend, S. (1956). The spectrophotofluorometric determination of tryptophan in plasma and of tryptophan and tyrosine in protein hydrolysates. $\mathcal{F}$. biol. Chem., 223, 313.

Evered, D. F. (1956). The excretion of amino acids by the human. Biochem. .7., 62, 416.

Halvorsen, K., and Halvorsen, S. (1963). Hartnup disease. Pediatrics, 31, 29.

Milne, M. D., Crawford, M. A., Girão, C. B., and Loughridge, L. W. (1960). The metabolic disorder in Hartnup disease. Quart. F. Med., 29, 407.

Moore, S., Spackman, D. H., and Stein, W. H. (1958). Chromatography of amino acids on sulfonated polystyrene resins. An improved system. Analyt. Chem., 30, 1185.

Sharlit, H. (1933). A method for quantitative estimation of indoxyl compounds in the urine. F. biol. Chem., 99, 537.

Weissbach, H., King, W., Sjoerdsma, A., and Udenfriend, S. (1959). Formation of indole-3-acetic acid and tryptamine in animals: a method for estimation of indole-3-acetic acid in tissues. ibid., 234, 81.

Wong, P. W. K., and Pillai, P. M. (1966). Clinical and biochemical observations in two cases of Hartnup disease. Arch. Dis. Childh., 41, 383. 